\title{
Editorial \\ Heterotopic and Neo-Victorian Affinities: Introducing the Special Issue on Neo-Victorian Heterotopias
}

\author{
Marie-Luise Kohlke ${ }^{1, *}$, Elizabeth $\mathrm{Ho}^{2, *}$ and Akira Suwa ${ }^{3, *}$ \\ 1 English Literature and Creative Writing, School of Culture and Communication, Swansea University, \\ Swansea SA2 8PP, Wales, UK \\ 2 School of English, University of Hong Kong, 7/F Run Run Shaw Tower, Centennial Campus, \\ Pokfulam, Hong Kong \\ 3 Language Education Center, Ritsumeikan University, Ibaraki, Osaka 567-8570, Japan \\ * Correspondence: m.l.kohlke@swansea.ac.uk (M.-L.K.); lizho@hku.hk (E.H.); \\ akira.suwa@alumni.york.ac.uk (A.S.)
}

check for updates

Citation: Kohlke, Marie-Luise, Elizabeth Ho, and Akira Suwa. 2022. Heterotopic and Neo-Victorian Affinities: Introducing the Special Issue on Neo-Victorian Heterotopias. Humanities 11: 8. https://doi.org/ 10.3390/h11010008

Received: 24 December 2021 Accepted: 30 December 2021 Published: 13 January 2022

Publisher's Note: MDPI stays neutral with regard to jurisdictional claims in published maps and institutional affiliations.

Copyright: (C) 2022 by the authors. Licensee MDPI, Basel, Switzerland. This article is an open access article distributed under the terms and conditions of the Creative Commons Attribution (CC BY) license (https:// creativecommons.org/licenses/by/ $4.0 /)$.

\begin{abstract}
The introduction to this special issue on Neo-Victorian Heterotopias investigates the affinities between the spaces designated by Michel Foucault's ambivalent and protean concept of 'heterotopia' and the similarly equivocal, shifting, and adaptable cultural phenomenon of 'neo-Victorianism'. In both cases, cultural spaces and/or artefacts prove deeply intertwined with chronicity, at once juxtaposing and blending different temporal moments, past and present. Socially produced sites of distinct emplacement are exposed not just as culturally and historically contingent constructs, but simultaneously enable forms of resistance to the prevailing ideologies that call them into being. The fertile exercise of considering heterotopias and neo-Victorianism in conjunction opens up new explorations of the Long Nineteenth Century and its impact on today's cultural imaginary, memory and identity politics, contestations of systemic historical iniquities, and engagements with forms of difference, non-normativity, and Otherness.
\end{abstract}

Keywords: compensation; crisis; cultural memory; deviation; Michel Foucault; heterotopia; identity politics; illusion; neo-Victorianism; Otherness

\section{Introduction: Curious Affinities}

First explored at length in Michel Foucault's 1966 radio talk 'Les hétérotopies' for Radio France, the concept of 'heterotopia' and the cultural sites it refers to gained widespread attention following the 1984 transcription of his lecture on the same topic, presented in 1967 to the Cercle d'études architecturales, a group of Paris-based architects, under the title 'Des espaces autres'. Two years later, in 1986, the lecture was first translated into English as 'Of Other Spaces'. Foucault's "counter-sites" (Foucault 1986, p. 24) or "counter-emplacements" (Foucault 2008, p. 17) evince curious affinities with the concept of 'neo-Victorianism', not least as regards the terms' inception points as theoretical concerns. Neo-Victorianism as a distinct form of creative practice likewise tends to be associated with the 1960s, which saw the publication of Jean Rhys's Wide Sargasso Sea (1966) and John Fowles's The French Lieutenant's Woman (1969), although the term 'neo-Victorian' only emerged some two decades later as a critical concept in response to a proliferation of predominantly, though not exclusively, English-language fictions that recouped nineteenth-century settings, literary classics, period lives, and tropes for present-day re-visitation, consumption, and critique. Today, the self-conscious re-imagining of the Long Nineteenth Century from present-day perspectives and its theorization termed 'neo-Victorianism' extends to myriad other genres and media, including film and television, drama, graphic novels, and computer games. In all of these, the primary heterotopias identified by Foucault, including prisons, asylums, brothels, ships, and colonies, tend to feature prominently. 
Since the 1980s, the notoriously fluid concepts of heterotopia and neo-Victorianism have attracted increasing critical engagement, the scope of which has far exceeded the terms' original usage and applications in the fields of architecture and literature. Indeed, the consideration of the two concepts in tandem is especially apt in view of Foucault himself having first employed the term 'heterotopia' in passing in Les mots et les choses: Une archéologie des sciences humaines (1966), translated into English as The Order of Things: An Archaeology of the Human Sciences (1970), specifically in relation to the fictions of Jorge Luis Borges, in spite of Foucault's concept first being applied in architectural circles. Hence Daniel Defert cites literary studies as "the site from which they [heterotopias] actually emerged" (Defert [2013] 2019, p. 90, translation our own), while Peter Johnson points out that 'Les hétérotopies' was actually "part of a series exploring utopia and literature" rather than architecture (Johnson 2013, p. 791). Kelvin T. Knight goes further still in asserting "that the concept was never intended as a tool for the study of real material sites, but rather pertains to fictional representations" or imagined and "semi-mythical places" (Knight 2017, p. 142; also see p. 147). Since 1966, however, the relevance of Foucault's heterotopia has expanded to behavioral studies, the leisure industries, discourses of cosmopolitanism and multiculturalism, and, in particular, "social and cultural geography, sociology and urban studies" (Johnson 2013, p. 790; also see Johnson 2016, pp. 5-6)—to the point that today "the range of different interpretations of the term" strikes many as "astonishing" (Heynen 2008, p. 312). The same could be said of neo-Victorianism, which has extended its tentacles into the realms of gender and queer studies, identity politics, narrative ethics, ecocriticism, the heritage industry, postcolonial studies, memory studies, trauma studies, architecture, and even politics, often engaging in cultural debates about contested histories and appropriate commemorations of colonial atrocities.

This introduction does not seek to explicate Foucault's concept in full, since the latter is already unpacked in this issue's individual contributions and capably analyzed elsewhere (see, e.g., Hetherington 1997; Faubion 1998; Dehaene and De Cauter 2008; Johnson 2013, 2016). Rather, we focus on the fertile affinities revealed by considering heterotopia and neoVictorianism in tandem, namely as cultural phenomena that facilitate new ways of thinking about the Long Nineteenth Century as defined by social spaces and their counter-structures or counter-emplacements. When probed, these sites can reveal the power relations that still exist as haunting legacies in the present. This approach is supported by Foucault's stress on the relational aspect of heterotopias, emphasized by today's "epoch of simultaneity" and "juxtaposition", which transforms the world into "a network" of interconnecting points (Foucault 2008, p. 14) that spans not just space but also time-hence Foucault's coinage of "heterochronies" (Foucault 1986, p. 26) or "heterochronism" (Foucault 2008, p. 20)encompassing both past and present societies. Aligning his concept with structuralism, Foucault describes said theoretical approach as "the effort to establish, between elements that could have been distributed over time, an ensemble of relations that makes them appear as juxtaposed, opposed, implicated by each other, in short, that makes them appear as a sort of configuration" (Foucault 2008, p. 14). Neo-Victorianism effects a comparable structuralist "configuration", implicating nineteenth-century past and postmodern present in each other's reciprocal formations.

Just as the past quite literally created the present, leaving its indelible imprint on today's architecture, ${ }^{1}$ institutions, and ideologies, such as those of gender and race, the present creates the past anew and gives it new forms by reproducing the nineteenth century on page, stage, screen and art, with the earlier period inevitably made to reflect our own time's vested interests and concerns. Reading specifically for neo-Victorian heterotopia opens up a new archive of literary and cultural production that offers up incongruous spaces for re-vision and contestation. Winsome Pinnock's play Rockets and Blue Lights (2020), for instance, centralizes the ship, but a very different kind of ship to Foucault's "heterotopia par excellence", radically transforming what Foucault describes as the "the greatest reserve of the imagination" (Foucault 1986, p. 27, original emphasis) into a floating cemetery and the reserve of trauma and horror. Deploying the ship as a neo-Victorian heterotopia, the 
play reveals Britain's oft-neglected history of slavery, correcting the usual bias, in education and popular consciousness, towards the country's 'heroic' role in Abolition in the context of the Black Lives Matter movement. In preparation for a cinematic production about the Zong slave ship massacre and its painting by J.M.W. Turner, the film cast's London rehearsal room becomes another stage for the whitewashing of history by progressively 'disappearing' black suffering, which should be central to the project, in favor of focusing on Turner (see Pinnock 2020, Act I, Scene 5, pp. 36-40). Similar to Foucault's description of the cinema screen and theater stage, the rehearsal room can thus be interpreted as a "heterotopia [ ... ] capable of juxtaposing in a single real place several spaces, several sites that are in themselves incompatible" (Foucault 1986, p. 25). Pinnock's drama itself thus transforms into an unsettling heterotopic site, in which history is literally contested, as the play, similar to the rehearsal space, simultaneously recovers the Otherness of nationalist history or what is excluded therefrom and restages its attempted continued repression. As Johnson pertinently points out, heterotopias encompass "a range of cultural, institutional and discursive spaces that are somehow 'different': disturbing, intense, incompatible, contradictory and transforming" (Johnson 2013, p. 790). Pinnock's play demonstrates how this is the case not only for those who inhabit these sites but also, potentially, for those outside them or merely passing through, including extradiegetic observers or audiences.

Beyond fictional examples and stagings, neo-Victorian heterotopias are quite real, their sudden reappearance around the globe revealing how heterotopias undergo "important changes" over time and are made to serve quite different functions (Foucault 1986, p. 25). To contextualize the importance of this special issue, at the time of writing this introduction, Canada is struggling with the discovery of hundreds of unmarked child graves at the sites of various residential Christian schools for First Nation children, set up as part of a program begun in the nineteenth century to forcibly assimilate the country's indigenous population and eradicate their culture, a process described by Canada's Truth and Reconciliation Commission in 2015 as 'cultural genocide' (see, e.g., Cecco 2021, n.p.). In much this sense, Canada is currently witnessing a crucial repurposing of these burial grounds as evidentiary crime sites of said cultural genocide, symbols of systemic racism, and markers of collective white and, in particular, the Church's institutional historical guilt. These (re)discovered sites illustrate how the violent and traumatic after-effects of the Long Nineteenth Century can be traced via a network of neo-Victorian heterotopias, since crime sites of deviancethat were also, in effect, prisons-now function as sites of commemoration for historical justice. Tracing the development of the function of heterotopia over time can help "mirror, or reflect" (Foucault 1986, p. 24) via discontinuity and rupture the sometimes troubled and contradictory needs of the present.

Put differently, we situate ourselves in the world via our simultaneous perceived continuity with and asserted difference from (or break with) the past or, as Foucault puts it, "space is given to us in the form of relations between emplacements" (Foucault 2008, p. 15) that always involve temporal as well as spatial (re-)negotiation. Knight glosses Foucault's fourth heterotopic principle as follows: "The heterotopia is at its most effective when it distorts the conventional experience of time" (Knight 2017, p. 143), i.e., linear, progressive, one-way time, always moving forwards into a supposedly more enlightened future. NeoVictorian works, like heterotopias, disrupt this seemingly inexorable onward movement, by mirroring the present in the re-presented nineteenth century and inviting audiences to simultaneously locate the lingering past at work within present-day social spaces, institutions, and government policy. In one sense, neo-Victorianism's self-production as a heterochronic relational space for artists and audiences to inhabit-and thereby virtually '(re-)experience' - the Long Nineteenth Century in the present (and the present in the past) renders the neo-Victorian text itself a kind of heterotopia. In addition to the already mentioned ambiguous fluidity and adaptability of the terms, we explore two further interrelated affinities between heterotopia and neo-Victorianism: the concepts' implicit utopian impulse, implicating the realm of the imaginary in the real, and their central focus on multiple forms of Otherness. These concerns also link directly to neo-Victorianism's 
investment in memory and identity politics, including explorations and contestations of systemic historical iniquities through heterotopic spaces.

\section{Ambiguous Indeterminacy}

Both heterotopia and neo-Victorianism have turned out to be exceptionally slippery, ambiguous terms, which critics struggle to pin down with regards to their exact significance and parameters. Part of the terms' indeterminacy results from the fact that the phenomena they are used to describe are often not culturally specific - as in the case of the ship that Foucault deems the ultimate "placeless place", the "heterotopia par excellence" (Foucault 1986, p. 27, original emphasis) or neo-slavery narratives written about any number of countries, continents, and colonies-but also because said phenomena often predate the two concepts' own emergence. Consequently, the terms always risk a degree of anachronism and self-reflexive presentist distortion, possibly re-imagining something other than it truly was. Foucault, e.g., looks back to Jesuit colonies in the New World to exemplify the heterotopic function of "compensation" (Foucault 1986, p. 27) and uses the gardens of ancient Persia and their aesthetic reproduction in Oriental rugs (Foucault 1986, pp. 25-26) - another mobile heterotopia similar to the ship-to illustrate the heterotopic function of "illusion" (Foucault 1986, p. 27) and, more expressly, his third principle: heterotopia's capacity to juxtapose myriad "incompatible" sites (Foucault 1986, p. 25), both real and imagined, actual places and aesthetic reflections thereof, within one-and-the-same space. Interestingly, Foucault's garden example also juxtaposes disparate historical periods: the contemporary commodity of the rug reflects ancient Persia, the "traditional" gardens of which mirror the very wellspring of life on Earth, with each garden's central water fountain symbolizing "the naval of the world" (Foucault 1986, p. 25), but also-though never explicitly stated-that most perfect of gardens, the mythical Eden itself. Foucault not only projects the Eurocentric concept of heterotopias into and onto the past but also onto other cultures in what could be read as an appropriative move, even a form of cultural colonialism.

Similarly, neo-Victorianism, both in terms of creative and critical practice, refuses to limit itself to the re-visioned realm of Queen Victoria or Britain's imperial territories at the time but, rather, incorporates the global Long Nineteenth Century while also evincing temporal 'creep' into the early twentieth century. ${ }^{2}$ This omnivorous agglomerating and assimilating tendency has raised concerns about possible 'improper' cross-cultural appropriation and cultural imperialism (Ho 2012, pp. 5-6, 12-13; Llewellyn and Heilmann 2013, pp. 26-28; Kohlke 2014, pp. 26-28), not least since the 'Victorian' embedded in 'neo-Victorian' evokes Britain's forcible colonization and annexation of foreign territories from the Caribbean to Hong Kong. Again analogous to Foucault's heterotopia, neo-Victorian works' own heterochronism injects present-day concerns, ideas, and theories - such as queer studies and postcolonialism - into past 'worlds' patently out of sync with such approaches. Kevin Hetherington aptly remarks that "[h]eterotopic relationships unsettle because they have the effect of making things appear out of place. The juxtaposition of the unusual creates a challenge to all settled representations; it challenges order and its sense of fixity and certainty" (Hetherington 1997, p. 50), including set ways of viewing/reading the past. Put differently, neo-Victorianism thrives on temporal disjunction and incongruence, which is repeatedly articulated spatially through re-imagined heterotopias.

Both 'heterotopia' and the 'neo-Victorian', then, have proven such highly productive terms exactly on account of their unsettling malleability and porous parameters, the way they refuse to be fixated or restricted to any particular geographical local or global contexts. This special issue thus celebrates the two terms' inherent 'openness', which Hilde Heynen views as essential to exploring heterotopias' "full potential as a thought-provoking concept that stimulates further investigations into the relationship between space and culture" (Heynen 2008, pp. 311-12), in our case specifically neo-Victorian culture. Both terms' simultaneous application to widely divergent and asynchronous contexts 'queers' notions 
of linear space-time, opening up alternate perspectives on the historical past as much as the present.

\section{The Utopian Impulse, Otherness and Societal Change}

Neo-Victorian heterotopias represent real and fictional counter-sites to nineteenth-century hegemonic cultural structures, systems, and symbolic orders embedded/located in the contemporary re-purposings and re-imaginings of period settings. Neo-Victorian heterotopias are themselves 'unreal', since they are primarily fictional or visual reproductions (except in the case of heritage sites). Nonetheless, they expose their extradiegetic counterparts and onetime "real places" (Foucault 1986, p. 24) —nineteenth-century prisons, asylums, cemeteries, etc.—as always historically and culturally contingent constructs, and hence contestable and (at least potentially) reformable. As Foucault does himself in his discussion of mirrors (see Foucault 1986, p. 24) and of carpets as figurative gardens, neo-Victorian heterotopias inevitably merge the real and phantasmatic. In the process, they expose such counter-sites' illusory dimension as not simply containing but producing/reproducing Otherness as a fantasy of declared difference projected onto often marginalized subjects and subalterns.

Prevailing ideologies at a particular historical moment produce specific kinds of 'crises' and forms of 'deviation' that call for management, sequestration and/or containment of potentially disruptive individuals via the creation of appropriate sites and institutions to which these may be relegated as Other-as that which mainstream culture defines itself against. Yet paradoxically, such counter-sites also contest as much as reflect the status quo, facilitating resistance to, interrogation and subversion of the very prevailing ideologies and hierarchical structures that produce them in the first place. One might think here of the nineteenth-century moral panic concerning the apparent dramatic upsurge of lunacy in Britain, which saw a doubling of the number of private asylums in just over three decades from 1815 to 1849 and, following the 1845 Lunacy Act, the mandated construction of county asylums also, with overcrowding common in both types of institutions (Torrey and Miller 2003, p. 70). Though not mentioned outright by Foucault in 'Of Other Spaces', the asylum, of course, belongs to the class of "heterotopias of deviation", alongside more modern "psychiatric hospitals" which, according to Foucault, progressively replaced earlier "heterotopias of crisis" (Foucault 2008, p. 18) reserved for subjects in transitory states of socio-culturally determined forms of Otherness (such as adolescence or menstruation). Unsurprisingly, the asylum trope also features prominently in neoVictorian fiction, in which it is predominantly used to explore power imbalances and historical gender abuses, and the still on-going global struggles for female self-liberation and equality. Neo-Victorian novels prominently employing the asylum trope include Sarah Waters's Fingersmith (2003), Kathy Hepinstall's Blue Asylum (2012), John Harwood's The Asylum (2013), Wendy Wallace's The Painted Bridge (2013), E. S. Thomson's Dark Asylum (2017, discussed in Kohlke's contribution to this volume), and Karen Cole's The Asylum (2021), among many others. The same heterotopia of deviance also features in neo-Victorian films and television series, for instance in Stonehearst Asylum (2014), directed by Brad Anderson, screenplay by Joe Gangemi (based on an Edgar Allen Poe short story), and Ava Bound's prize-winning student short Beth (2020).

Neo-Victorian heterotopias thus invite audiences, consumers, and scholars of neoVictorian cultural products to rehearse different patterns of thinking, feeling, and being in line with the utopian impulse discerned in heterotopia by Foucault himself and subsequent explicators of his concept. Iwan Sudradjat, for instance, draws on David Harvey's and Bart Lootsma's readings of Foucault in relation to urban space to stress how heterotopias make space for and "give way to otherness, and otherness subsequently opens a door to plurality and heterogeneity" (Sudradjat 2012, p. 32). ${ }^{3}$ Sudradjat goes on to assert that Foucault "calls for a city with many heterotopias, not only as a space with several places of / for the affirmation of difference, but also as a means of escape from authoritarianism and repression" (Sudradjat 2012, p. 32). Hence heterotopias contest the very possibility 
of confining Otherness to Other spaces, separate from society, instead locating Otherness at its very heart. Instead of peripheral, heterotopias are central to-and constitutive of-communities and play a crucial part in society's evolution, by reflecting both the latter's utopian aspirations and shortfalls from its best intentions, thus actively promoting change. In Hetherington's words, "[h]eterotopia are spaces of the 'not yet' as Ernst Bloch might have called them, spaces that seek to turn that 'not yet' into a 'there' but never achieve their place in an order of things" (Hetherington 1997, p. 141). Similar to the dreams carried by the ship, that paradigmatic Other "floating piece of space [ ... ] given over to the infinity of the sea" (Foucault 1986, p. 27) and distant horizons of possibility, heterotopias thus also project 'what might yet be', not just in the nineteenth-century's future but also our own.

Similarly, neo-Victorianism's repeated focus on ex-centric subjects and marginalized voices-for instance, exploited and dehumanized colonial subjects, freak show performers, prostitutes, homosexuals, servants, and criminals-displays utopian tendencies aimed at a fairer and more inclusive reckoning with history. As well as counteracting the normative exclusions from white-washed nationalistic versions of the past, many neo-Victorian texts attempt to dispense symbolic justice through commemorating forgotten wrongs or imagining historical perpetrators' comeuppance for crimes against those defined as Others and hence as disposable and dispensable. In part a recovery project of silenced or disregarded histories, neo-Victorianism presents alternative versions of the past that rupture any notion of a homogenous nineteenth century or of homogenous populations in British or global contexts at the time, much as Foucault's heterotopia underlines society's heterogeneity through its spatial organization. Encouraging audiences to review their limited, often reductive or stereotypical notions of 'the Victorian', neo-Victorian heterotopias reposition Foucault's Other spaces as central to appreciating the complex heterogeneity of the period and its relations to the present, and to interrogating the extent of social 'progress' achieved since the nineteenth-century fin-de-siècle, not least in terms of human rights and civil liberties. While nineteenth-century counter-sites can also be appropriated for reactionary and repressive reuse (see, e.g., Esser's and Ho's contributions to this volume), both heterotopias and neo-Victorianism are thus potentially 'catalytic' of social change, by exposing and reconfiguring the cultural imaginary that underpins society's structures and institutions.

\section{Myriad Neo-Victorian Heterotopias: The Contributions}

The contributors to this special issue explore a variety of neo-Victorian re-imaginings of nineteenth-century heterotopias, both literal and fantastical, revisiting a range of Foucauldian counter-sites as well as introducing some new ones. Helena Esser's 'Re-Calibrating Steampunk London: Heterotopia and Spatial Imaginaries in Assassins Creed: Syndicate and The Order 1886' considers the role of two video games with steampunk elements in both reprising and contesting class issues in cultural memory. Esser argues that the games' "outlaw spaces" deploy a re-imagined Victorian London as a heterotopic playground for audiences to explore possibilities for historical agency while also placing limits thereon. According to Esser, the virtual urban imaginary simultaneously foregrounds exclusionary politics and oppositional practices of resistance through spatial engagement, juxtaposing players' freedom and mastery to manoeuvre and 'right' historical wrongs with a state of powerlessness to effect substantive change in the game plan. Hence the video games end up re-orientating the player through immersive and defamiliarizing "thought experiments", which compel them to recognize "the stratified power" that the city "enshrines" in the games' alternative nineteenth-century pasts as well as the present.

Barbara Braid's 'Neo-Victorianism as a Cemetery: Heterotopia and Heterochronia in Tracy Chevalier's Falling Angels and Audrey Niffenegger's Her Fearful Symmetry' explores the heterotopic and heterochronic nature of the cemetery. Braid argues that neo-Victorianism's spatial and temporal engagement has much in common with Foucault's principles of heterotopia, especially in that both serve to "collapse distinctions between past 
and present into palimpsestic conjunction". If heterotopias are inherently spectral, enclosing and containing multiple spatialities at once, then the cemetery emerges as a reified space that can also be made to speak for neo-Victorianism's enclosure of the past within the present. Through the analysis of two neo-Victorian novels in which Highgate Cemetery represents the juxtaposition of different spaces and time periods, Braid demonstrates that both heterotopias and neo-Victorianism engage in "a hauntological project" of simultaneously "being present and absent".

The co-editor Elizabeth Ho's 'Heterotopic Heritage in Hong Kong: Tai Kwun and Neo-Victorian Carceral Space' explores the heritage site Tai Kwun in Hong Kong. An adaptive reuse project and restoration of a police station and colonial prison complex as well as a contemporary art museum, Tai Kwun both embodies and complicates several of Foucault's heterotopic principles. Examining the ways in which the visitor's gaze is 'incarcerated' by the dominant narratives and spatialites of order and control of the site, Tai Kwun challenges the celebratory aspects of heterotopia as transgressive counter-site. Instead, 'Otherness' is increasingly 'Victorianized' to support rather than disrupt (neo-)colonial power relations. Tai Kwun's spatial, historical and financial arrangements, recontextualized within Hong Kong's postcolonial context, pose new questions of Foucault's original definition of heterotopia and our conception of the politics of neo-Victorianism in the present.

Charlotte Wadoux's "“The World Had Forgotten About Us": Heterotopian Resistance in Richard Flanagan's Wanting and Lloyd Jones's Mister Pip' demonstrates how reading for heterotopic spaces and principles in postcolonial neo-Victorian fiction can reveal "palindromic" spatial relationships of past and present, colony and metropole. Wadoux's article traces a number of heterotopic spaces such as the ship, the penal colony and the island in two neo-Victorian novels that reference Dickens's Great Expectations (1860-1861) in order to rewrite and reinterpret Australia as the 'Other space' to England. By charting how sites develop and expand on Foucault's heterotopic principles over the course of both novels, Wadoux proposes new modes of reclaiming the past in spatial terms that prompt a re-evaluation of "Eurocentric representations" of the former colonies and competing identity politics.

Sara K. Day and Sonya Sawyer Fritz's 'Young Adult Crisis Heterotopias and Feminist Revisions in Colleen Gleason's Stoker and Holmes Series' takes neo-Victorian Young Adult (YA) fiction as its focus. One of several essays in this special issue that examines steampunk's revision of Victorian London, Day and Sawyer Fritz's article demonstrates how commonly deployed neo-Victorian heterotopias, such as the garden and the museum, "mirror twenty-first century feminist ideals". Navigating neo-Victorian heterotopias in Gleason's Stoker and Holmes series (2013-2019) shows how YA fiction can create pseudoheterotopias of crisis for their female protagonists that offer limited opportunities for subversion or social critique. Instead, the transgressive potential of heterotopic space is given over to the novels' villain, whose deviance is deemed excessive and must be excised from the text. Ultimately, the ability of neo-Victorian YA fiction to deploy heterotopic spaces as transgressive for female characters and young adult readers is deemed disappointingly limited.

Courtney Krentz, Mike Perschon, and Amy St. Amand's 'Their Own Devices: Steampunk Airships as Heterotopias of Crisis and Deviance' also takes two steampunk Young Adult (YA) series as their primary examples of how neo-Victorian heterotopia can create new imaginary geographies in which to explore solutions to real problems, specifically of race and gender. The authors focus on the steampunk airship in Scott Westerfeld's Leviathan trilogy and Gail Carriger's Finishing School series as a revision of Foucault's claim that the "sailing vessel is the heterotopia par excellence" imbued with utopian potential. As the protagonists ride the steampunk airship towards "social frontiers of gender and race", the authors contend, the airships transform from heterotopias of deviance into ones of crisis, blurring Foucault's distinctions between the two. At the same time, they provide 
their "readers with literary maps for their uncertain real worlds of crisis" during their own maturation process.

The co-editor Akira Suwa's 'Heterotopic Potential of Darkness: Exploration and Experimentation of Queer Space in Sarah Waters's Neo-Victorian Trilogy' considers darkness as a crucial factor in challenging dominant heteronormative ideologies in Sarah Waters's three neo-Victorian novels. According to Suwa, while much critical attention has focused on concrete spaces such as prisons and theaters in Waters's fiction, it is darkness that has the potential to make these spaces heterotopic by creating "an ambiguous mix of various, often contradictory, concepts". In this incongruous space, Waters's queer characters are allowed to experiment with the possibility of invalidating heteronormativity and with imagining futures that would accommodate their non-normative desires. Suwa further proposes that darkness serves to expand the concept of Foucault's heterotopia. By offering imaginative ways of dealing with the past, both neo-Victorian fiction and heterotopias urge us to question the construction and enforcement of ideological and spatial boundaries.

Marlena Tronicke's 'Heterotopian Disorientation: Intersectionality in William Oldroyd's Lady Macbeth' considers the gender and racial politics in Lady Macbeth (2016), focusing on the film's representation of "highly symbolic spatial structures" such as the country house. Tronicke reads the house as a neo-Victorian heterotopic site within which multiple characters are physically and ideologically imprisoned and oppressed. Nonetheless, Tronicke argues, the film collapses colonial and domestic space in order to create visual and ideological disorientations that both contest White hegemony and expose "the pervasiveness of intersectional forms of oppression that are at play in both Victorian and twenty-first-century Britain". Analyzing the "cinematography of incarceraton" affecting both Katherine Lester and her Black housemaid, Anna, Tronicke also demonstrates the limits in Foucault's conception of heterotopias around issues of intersectionality and interrogations of White privilege so crucial to both twenty-first-century feminism and neo-Victorian studies.

Elisavet Ioannidou's 'From Crisis to Compensation: Reinventing Identity and Place in the Sideshow and the Laboratory' identifies how neo-Victorian texts are "sympathetic" towards the utopian qualities underpinning the discussion of heterotopia's principles, especially regarding spatial mobility. Ioannidou explores how neo-Victorian heterotopias emphasize movement and passage rather than exclusion and compartmentalization by comparing the sideshow in Leslie Parry's Church of Marvels (2015) and the laboratory in NBC's Dracula (2013) as relational to the metropolises (New York and London respectively) in which they are embedded. As conventionally abhorrent characters such as the freak or the vampire emerge from spaces usually deemed as "counter-sites" to mainstream spatial order, past and present, they are expelled into the city where their inclusion and visibility transform urban spaces into "heterotopias of compensation" that serve neo-Victorianism's agenda of tolerance and empowerment.

The co-editor Marie-Luise Kohlke's 'Heterotopic Proliferation in E.S. Thomson's Jem Flockhart Series' focuses on Thomson's detective series (2016-2021) about a female cross-dressing apothecary in mid-nineteenth-century London, in which a plethora of Foucauldian counter-sites collapse into each other while the garden replaces Foucault's ship as the paradigmatic Other space. The series' enclaves of Otherness-not least the protagonist Jem's non-normative liminal body situated both inside and outside of mainstream culture-foreground the city's unequal power relations and intersectional forms of discrimination, undermining any straightforward reading of heterotopias as marginal spaces of resistance. At the same time, Thomson's novels throw into relief Foucault's problematic disregard of agency and multi-directional power operating in heterotopic spaces. Kohlke contends that the sheer multitude of counter-sites in Thomson's series indicates that heterotopia has become a crucial, even essential feature of today's spatialized cultural imaginary of the Long Nineteenth Century. 


\section{Conclusions}

This special issue suggests that neo-Victorianism tends to privilege two of the three models outlined by Heynen to conceptualize "the relationship between space and social processes", discounting the first model of space "as a relatively neutral receptor and reflector of socio-economic or cultural processes" (Heynen 2008, p. 314, original emphasis). Instead, neo-Victorianism portrays heterotopic space as an active and foundational component of these same processes, including operations of crucial memory-work as a form of spatiotemporal engagement with the past. As per Heynen's second model, neo-Victorian works present "spatial articulations as possible instruments in bringing about particular social processes", reading "the built environment [ ... ] as the instigator of social or cultural change", with heterotopias providing the "spatial tools for the regulation of behaviour, the disciplining of the body or the activation" of particular forms "of social interaction" (Heynen 2008, p. 314, original emphasis). In particular, these interactions continuously renegotiate and redefine changing cultural constructions of Otherness. Alternatively and sometimes simultaneously, in line with Heynen's "third thought model", neo-Victorian works envisage the nineteenth-century past's "built environment as a stage on which social processes are played out", directing "actions and interactions" and "fram[ing] social transformations" (Heynen 2008, p. 314, original emphasis). Indeed, neo-Victorian works themselves become such heterotopic 'stages' for rethinking our spatio-temporal relations with the Long Nineteenth Century and the kinds of transactions these enable or disable, validate or refuse to recognize, re-imagine or conveniently try to forget and disavow.

Author Contributions: Three authors contributed to its conception, methodology, and writing. All authors have read and agreed to the published version of the manuscript.

Funding: This research received no external funding.

Institutional Review Board Statement: Not applicable.

Informed Consent Statement: Not applicable.

Data Availability Statement: Not applicable.

Conflicts of Interest: The authors declare no conflict of interest.

\section{Notes}

See, e.g., Ho's contribution to this volume.

See, e.g., Courtney Krentz, Mike Perschon, and Amy St. Amand's discussion of neo-Victorian steampunk's typically 'Edwardian' dirigibles in this special issue.

3 The critic refers to David Harvey's The Condition of Postmodernity (1989) and Bart Lootsma's 'Bas Princen, Of Other Spaces, (re)vis(it)ed' (2008).

\section{References}

Cecco, Leyland. 2021. Canada Discovers 751 Unmarked Graves at Former Residential School. The Guardian, June 24, n.p. Available online: https://www.theguardian.com/world/2021/jun/24/canada-school-graves-discovery-saskatchewan(accessed on 8 July 2021).

Defert, Daniel. 2019. Raum zum Hören [Afterword]. In Michael Foucault: Die Heterotopien/Les hétérotpies; Der utopische Körper/Le Corps Utopique. Frankfurt am Main: Suhrkamp, pp. 67-92. First published 2013; French version as CD in 2004.

Dehaene, Michiel, and Lieven De Cauter, eds. 2008. Heterotopia and the City: Public Space in a Postcivil Society. London and New York: Routledge.

Faubion, James D., ed. 1998. Aesthetics, Method, and Epistemology: Essential Works of Foucault 1954-1984. London: Penguin, vol. 2.

Foucault, Michel. ; Translated by Jay Miskowiec. 1986. Of Other Spaces. Diacritics 16: 22-27. Lecture from 1967, first published in French in 1984. [CrossRef]

Foucault, Michel. 2008. Of Other Spaces. In Heterotopia and the City: Public Space in a Postcivil Society. Translated and Edited by Michiel Dehaene, and Lieven De Cauter. London and New York: Routledge, pp. 13-29. Lecture from 1967, first published in French in 1984

Hetherington, Kevin. 1997. The Badlands of Modernity: Heterotopia and Social Ordering. London: Routledge. 
Heynen, Hilde. 2008. Heterotopia Unfolded? In Heterotopia and the City: Public Space in a Postcivil Society. Edited by Michiel Dehaene and Lieven De Cauter. London: Routledge, pp. 311-23.

Ho, Elizabeth. 2012. Neo-Victorianism and the Memory of Empire. London and New York: Continuum.

Johnson, Peter. 2013. The Geographies of Heterotopia. Geography Compass 7, 11: 790-803. [CrossRef]

Johnson, Peter. 2016. Interpretations of Heterotopia (Revised). Heterotopian Studies. Available online: http:/ / www.heterotopiastudies. com (accessed on 15 March 2020).

Knight, Kelvin T. 2017. Placeless Places: Resolving the Paradox of Foucault's Heterotopia. Textual Practice 31, 1: 141-58. [CrossRef]

Kohlke, Marie-Luise. 2014. Mining the Neo-Victorian Vein: Prospecting for Gold, Buried Treasure, and Uncertain Metal. In Neo-Victorian Literature and Culture: Immersions and Revisitations. Edited by Nadine Boehm-Schnitker and Susanne Gruss. New York and London: Routledge, pp. 21-37.

Llewellyn, Mark, and Ann Heilmann. 2013. The Victorians Now: Global Reflections on Neo-Victorianism. Critical Quarterly 55, 1: 24-42. [CrossRef]

Pinnock, Winsome. 2020. Rockets and Blue Lights. London: Nick Hearn Books.

Sudradjat, Iwan. 2012. Foucault, the Other Spaces, and Human Behaviour. Procedia-Social and Behavioral Sciences 36: 28-34. [CrossRef]

Torrey, E. Fuller, and Judy Miller. 2003. The Invisible Plague: The Rise of Mental Illness from 1750 to the Present. Piscataway: Rutgers University Press. 